DOI: 10.34015/2523-4552.2019.3.17

УДК 342.9 (477)

Шурко О. I., здобувач Інституту права та суспільних відносин Відкритого міжнародного університету розвитку людини «Україна» e-mail: Shurko25@i.ua

ORCID ID: 0000-0003-1428-035X

\title{
ЗАКОННІСТЬ ЯК КЛЮЧОВА ЗАСАДА ЗАБЕЗПЕЧЕННЯ ОХОРОНИ ТА ПІДТРИМАННЯ ГРОМАДСЬКОГО ПОРЯДКУ В СУДАХ
}

У статті узагальнюються наукові підходи щодо визначення сутності таких понять як «забезпечення законності» та «законність», на основі чого пропонується власне визначення змісту цих категорій. Наголошується, що в юридичній літературі поняття судочинство ототожнюється із категорією правосуддя. Акцентовано увагу на наукових підходах до розуміння термінів громадський порядок та публічний порядок. Проаналізовано їх співвідношення. Встановлено, що у найбільш загальному розумінні законність необхідно тлумачити як вихідну засаду, ідею, що лежить в основі здійснення будь-якої діяльності, незалежно від того, про яку сферу суспільних відносин йдеться. Вона, перш за все, передбачає неухильне слідування всіма суб'єктами права норм чинного законодавства, а відтак сприяє забезпеченню панування правопорядку в суспільстві.

Ключові слова: законність; судочинство; правосуддя; правопорядок; громадський порядок; публічний порядок.

В статье обобщаются научные подходы к определению сущности таких понятий как: «обеспечение законности» и «законность», на основе чего предлагается собственное определение содержания этих категорий. Отмечается, что в юридической литературе понятие судопроизводство отождествляется с категорией правосудия. Акцентировано внимание на научных подходах к пониманию терминов общественный порядок и публичный порядок. Проанализированы их соотношение. Обосновано, что законность, как ключевая основа обеспечения охраны и поддержания общественного порядка в судах, имеет два ключевых аспекта: во-первых, она направлена на то, чтобы обеспечить в пределах установленных законом деятельность судов, которая была правомерной и соответствовала нормам действующего законодательства, а также мировым стандартам, являющимися общепризнанными в этой сфере; а вовторых, законность предполагает, что суды имеют возможность без внешнего воздействия на судебный процесс осуществлять правосудие и выносить справедливые и законные решения, тем самым обеспечивая надлежащую защиту прав и свобод граждан, а как результат господства права в обществе. 
Ключевые слова: законность; судопроизводство; правосудие; правопорядок; общественный порядок; публичный порядок.

Постановка проблеми. Сьогодні нікого не треба переконувати, що правосуддя $\epsilon$ фундаментом держави. Це відомо з давніх-давен. Одночасно воно $є$ обличчям держави. Останню сприймають насамперед за рівнем правосуддя, оскільки людині потрібні не тільки хліб і видовища, а й справедливість [1]. Діяльність судів становить універсальний механізм із захисту й охорони права, відновлення порушеного права, припинення порушення права. Правосуддя $\epsilon$ квінтесенцією регуляційної й охоронної функції держави, які доповнюють одна одну, оскільки в них втілено охорону Конституції, суб'єк-тивного права, відновлення порушеного права, підтримання правопорядку і законності [2, с.22]. На жаль, із законністю та справедливістю в нашій державі сьогодні - певні проблеми. Вони стали майже основною політичною складовою її відносин з іншими державами світу й фактично створюють відповідний імідж України [1].

Аналіз останніх досліджень i публікацій. Проблема забезпечення законності судочинства неодноразово потрапляла у поле зору різних науковців. Зокрема їй приділяли увагу: О. С. Захарова, В. С. Ковальський, В. С. Лукомський, $€$. Ю. Бараш, В. С. Бігун, О.Ф. Скакун, Н. Ю.Задирака, Ю. І. Римаренко, Я. Ю. Кондратьєв, А. В. Малько, О. М. Музичук, А. Ф. Крижановський, В. В. Комаров, О. Л. Копиленко, Н. М. Оніщенко, О. В. Зайчук та багато інших. Разом із тим, незважаючи на чималу кількість наукових розробок, в юридичній літературі ще й досі не сформовано єдиного погляду з приводу того, що взагалі пред- ставляє собою законність, як ключова засада забезпечення охорони та підтримання громадського порядку в судах.

Постановка завдання. Мета статті - дослідити зміст законності, як ключової засади забезпечення охорони та підтримання громадського порядку в судах.

Виклад основного матеріалу. Починаючи розгляд основного питання в першу чергу слід звернути увагу на те, що взагалі представляють собою категорії «громадський порядок» та «публічний порядок» та як вони співвідносяться. Так, 3 метою з'ясування співвідношення зазначених понять, звернемося до наукових підходів до тлумачення їх змісту. Так, наприклад, I. І. Плохой вважає, що громадський порядок - це система відносин, належний порядок, що склався у суспільстві, який відповідає інтересам держави та всіх іï громадян [3]. В. Я. Настюк у своїх працях пише, що зміст громадського порядку утворює система суспільних відносин, які складаються в результаті суворого виконання і додержання норм права, моральних норм, позитивних правил-звичаїв [3]. М. В. Корнієнко розуміє громадський порядок як обумовлену потребами суспільства систему врегульованих соціальними нормами відносин, що виникають в громадських місцях у процесі спілкування людей, яка має на меті забезпечення сприятливої обстановки функціонування суспільного життя, нормальних умов для праці та відпочинку людей, для діяльності державних органів, підприємств, установ та організацій 
[5, с. 14]. На думку О. Ф. Скакун, громадський порядок - зумовлений об'єктивними і суб'єктивними чинниками стан урегульованості та організованості порядку у громадських місцях, що складається на основі реалізації всіх соціальних норм i принципів (правових, моральних, релігійних, корпоративних тощо) $[18$, с. 508]. Ю. С. Небеський, аналізуючи поняття громадського порядку, дійшов висновку, що під ним слід розуміти порядок, який включає до себе усю систему позитивних та негативних суспільних відносин (відносин державних органів між собою, державних органів та громадських організацій чи громадян), метою яких є охорона життя, здоров'я, честі, гідності громадян, їх законних інтересів, забезпечення громадського спокою як у громадських місцях, так і поза їх межами, збереження усіх форм власності, створення реальних умов для нормального функціонування державних органів, громадських організацій і трудових колективів, та які регулюються соціальними нормами (як нормами права, так i іншими соціальними нормами неюридичного характеру) [6, с. 16].

Щодо публічного порядку, то М. М. Мальський веде мову про «публічний порядок» як один із основоположних принципів, змістом якого $€$ захищеність головних суспільних інтересів у разі виникнення спорів 3 іноземним елементом та визнання i виконання іноземних судових piшень національними судовими установами [7, с. 79]. О. О. Панова надає визначення «публічного порядку» як державного ладу, упорядкованості суспільних відносин, призначеного для забезпечення прав і свобод людини й громадянина, під час якого органи державної влади, органи місцевого самоврядування i кожна окремо визначено особа мають дотримуватися загальноприйнятих норм нормального співіснування [8]. Існує точка зору, згідно якої публічний порядок - це публічно-правові відносини, що мають імперативний характер і визначають основи суспільного ладу держави» [8].

Щодо нормативно-правового закріплення термінів громадський та публічний порядок, варто відзначити, що оновлення та вдосконалення українського законодавства, його пристосування до міжнародних вимог i стандартів супроводжується впровадження нових термінів та термінологічних конструкцій, при цьому нормотворець, досить часто, не надає їм чіткого визначення. Зокрема така ситуація склалася із поняттям «публічний порядок», захист якого, із прийняттям 2 липня 2015 року закону «Про національну поліцію» № 580-VIII, було визнано $\epsilon$ одним із основних завдань національної поліції. Наразі на офіційному рівні дана понятійно-термінологічна конструкція розтлумачена лише у Постанові Пленуму Верховного Суду України «Про практику розгляду судами клопотань про визнання й виконання рішень іноземних судів та арбітражів і про скасування рішень, постановлених у порядку міжнародного комерційного арбітражу на території України» № 12 від 24.12.99 р., згідно якої під публічним порядком належить розуміти правопорядок держави, визначальні принципи i засади, які становлять основу існуючого в ній ладу (стосуються іï незалежності, цілісності, самостійності й недоторканності, основних конституційних прав, свобод, гарантій то- 
що) [11]. Звідси постає цілком логічне питання про те, як «публічний порядок» співвідноситься із терміном «громадський порядок», який був закріплений у попередньому законі «Про міліцію» від 20 грудня 1990 року № 565-XII, та використовується у ряді чинних нормативноправових актів. Так, наприклад, у Законі «Про національну безпеку України» від 21 червня 2018 року № 2469-VIII йдеться про громадську безпеку і порядок, які являють собою захищеність життєво важливих для суспільства та особи інтересів, прав і свобод людини і громадянина, забезпечення яких $\epsilon$ пріоритетним завданням діяльності сил безпеки, інших державних органів, органів місцевого самоврядування, їх посадових осіб та громадськості, які здійснюють узгоджені заходи щодо реалізації і захисту національних інтересів від впливу загроз [12]. Про громадський порядок ведеться мов і Законі України «Про особливості забезпечення громадського порядку та громадської безпеки у зв'язку з підготовкою та проведенням футбольних матчів» від 08.07.2011 № 3673-VI, в якому його визначено як сукупність суспільних відносин, що забезпечують нормальні умови життєдіяльності людини, діяльності підприємств, установ і організацій під час підготовки та проведення футбольних матчів шляхом встановлення, дотримання і реалізації правових та етичних норм [13]. Натомість у змісті вище згаданого закону «Про національну поліцію», а також Положенні про патрульну службу МBC, затвердженого Наказом МВС від 02.07.2015 № 796 [14] присутні обидва поняття - і громадський порядок, і публічний порядок, при цьому відсутність хоча б якихось вказівок щодо їх розмежування свідчить про те, що нормотворець використовує їх як синоніми.

Враховуючи вище викладене, вважаємо, що попре суттєву змістовну схожість «громадський порядок» та «публічний порядок», все ж таки, не тотожні поняття. Адже коли йдеться про публічність, то мається на увазі, перш за все, відкритість, гласність, прилюдність. Натомість «громадський»-це такий, що виникає, відбувається в суспільстві або стосується суспільства, пов язаний iз ним; - належний усій громаді, усьому суспільству; колективний [10, с. 1187]. Тобто публічність радше характеризує принцип організації здійснення чогось - політики, якихось заходів. У свою чергу термін «громадський» вказує на зв'язок із суспільством, орієнтованість на наявні у ньому суспільні відносини та зв'язки. Звідси можемо дійти висновку, що вести мову про публічний порядок доцільно у контексті міжнародних стосунків, принципів організації та діяльності органів державної влади, їх взаємовідносин між собою. Натомість, коли йдеться про порядок як стан урегульованості суспільних відносин, поведінки у громадських містах, охорону та захист даного порядку, слід вести мову не про публічний, а саме громадський порядок. Тож вбачається, що у контексті забезпечення охорони та підтримання порядку в судах варто вести мову саме про громадський порядок.

Щодо розуміння принципу законності, то варто відзначити, що дослідженню цього принципу досить багато уваги приділяється вченими. Так, визнаючи багатогранність поняття «законність», М. І. Матузов вважає, що вона має доволі просте та 
стисле визначення. Під законністю треба розуміти суворе й неухильне дотримання усіма суб'єктами права існуючих у державі законів та заснованих на них підзаконних нормативних актів. Ключовим словом у наведеній дефініції $є$ «дотримання». Саме у ньому визначальний зміст і сутність розглядуваного явища у будьякій його інтерпретації, бо якщо немає дотримання, то немає і законності. Учений слушно стверджує, що поняття законності повинно розповсюджуватися не тільки на сферу дії законів, а й на усю сферу їх утворення, тобто законотворчість, а ширше на усю правотворчість, тому що ці процеси також піддаються оцінці 3 позиції ідей моральності та законності. Акцентовано увагу на тому, що закони повинна поважати насамперед влада, інакше законність виявиться неповною, обмеженою, а влада - не правовою [15, с. 408-410].

А. С. Кравцов відзначав, що законність навряд чи можливо визначати як стан суспільної життєдіяльності, який визначається ступенем відповідності чинному законодавству, бо це елемент правового порядку, який не може бути виокремлений 3 загального стану правової впорядкованості суспільного буття. Законність наявних правових відносин суспільстві «розчиняється» у сукупності всіх суспільних відносин, які грунтуються на вимогах права і виходять із його приписів $[16$, с. 34$]$. Ідея законності, підкреслює С. С. Алєксєєв, формується у правовій свідомості, це ідея про доцільність і необхідність такої реальної правової поведінки всіх учасників суспільних відносин, за якої не залишалось би місця для свавілля, фактично досягалась всезагальність права дійсна реалізація суб'єктивних прав $[17$, c. $219 ; 16$, с. 33].

О.Ф. Скакун вказувала, що законність, як багатогранне явище, може виступати як принцип, метод, режим. Законність як принцип - провідне загальноприйняте правило імперативного характеру, що виражене у нормах-ідеях найвищого авторитету і потребує від державних органів та їх посадових осіб, громадян та їх об'єднань діяти правомірно, у межах правових норм, закріплених y приписах усіх чинних джерел (форм) права. Законність як метод система правових засобів, якими здійснюється державне управління суспільством, згідно з яким органи держави i посадові особи: 1) спираються на визнання та беззастережне прийняття найвищої цінності людини при розробленні і прийнятті рішень; 2) не підмінюють своїм регулюванням (тобто актами управління) закон; 3) не виходять за межі своєї компетенції, що визначена законом, при реалізації прийнятих рішень; 4) додержуються правових процедур у процесі контролю і нагляду за законністю дій учасників суспільних відносин тощо. Метод законності (його називають законністю управління) $є$ основою застосування інших методів державного управління: організації, примусу, виховання, контролю та ін. Законність як режим - стан правової організації суспільно-політичного життя, за якого суспільні відносини, правова поведінка, правова діяльність, інша правова активність людини здійснюються відповідно до законів та інших джерел (форм) права, котрі відповідають принципу верховенства права, правовим цінностям свободи, формальної рівності, справедли- 
вості. За режиму законності встановлюється правова атмосфера, де неухильно здійснюються (додержуються, виконуються, використовуються, застосовуються) чинні правові норми усіма суб'єктами права (державними органами, посадовими особами, громадянами та їх об'єднаннями), де панують ідеї права, гуманізму, справедливості, свободи й відповідальності; особа захищена від сваволі влади, суспільство - від анархії, хаосу, безладдя й насильства $[18$, c. 495-496].

М. Г. Александров розрізняв законність у широкому і вузькому аспектах. В широкому аспекті законність становить принцип поведінки, яка вимагається державою від усіх громадян, посадових осіб, установ i організацій. Цей принцип означає, що вимоги дотримуватися закону (i виданих на виконання законів підзаконних актів) висуваються рівною мірою до всіх без винятку громадян, посадових осіб, установ і організацій $[19$, с. 105]. Законність у вузькому розумінні визначалась як принцип діяльності соціалістичного державного апарату. У цьому аспекті соціалістична законність означає, що здійснення всіх владних дій (і особливо державного примусу) має проходити винятково в межах закону, на основі точного і неухильного виконання законів за суворого і неухильного виконання всіма посадовими особами прав і законних інтересів громадян [19, с. 105].

А. В. Сагун також веде мову про широке та вузьке розуміння сутності забезпечення законності. В широкому розумінні забезпечення законності «починається» 3 визначення норм, які повинні дотримувати певні суб'єкти і включає ряд попереджува- льних, встановлювальних, захисних, відновлювальних, каральних дій суб'єктів забезпечення законності. Тим самим проводимо різницю між контролем і наглядом у судовій системі та процесом забезпечення законності. Ці два поняття відносяться як частина і ціле. Це означає, що поняття забезпечення законності ширше, і не обмежено контрольними заходами. У вузькому розумінні сутність забезпечення законності можна встановити шляхом аналізу сутності контролю [20, с. 182].

У рамках нашого дослідження слід вказати думку О.В. Зайчука, який пише, що принцип законності вимагає від судів, щоб всі процесуальні документи бути законними, грунтованими, мотивованими, справедливими, логічними, грамотно і культурно оформленими та в цілому високоефективними. Зміст забезпечення законності здійснення правосуддя відрізняється від забезпечення законності управлінської діяльності суду Іншими словами, щодо управлінської діяльності, яка $\epsilon$ частиною компетенції ряду елементів судової системи забезпечення принципу законності. Сутність принципу законності в управлінській діяльності судів полягає у тому, що він має єдине значення як режим (стан) відповідності дій, поведінки, діяльності посадових осіб, громадян та юридичних осіб законам і підзаконним нормативно-правовим актам держави, який утворюється в результаті неухильного додержання останніх усіма суб'єктами права [20, с. 121].

Таким чином, у найбільш загальному розумінні законність слід тлумачити як вихідну засаду, ідею, що лежить в основі здійснення будьякої діяльності, незалежно від того, 
про яку сферу суспільних відносин йдеться. Вона, перш за все, передбачає неухильне слідування всіма суб'єктами права норм чинного законодавства, а відтак сприяє забезпеченню панування правопорядку в суспільстві.

Висновки. Отже, завершуючи представлене наукове дослідження слід узагальнити, що законність, як ключова засада забезпечення охорони та підтримання громадського порядку в судах, має два аспекти: поперше, вона спрямована те, щоб забезпечити в межах встановлених законом діяльність судів, яка була б правомірною та відповідала нормам чинного законодавства, а також світовим стандартам, які є загальнови- знаними у цій сфері; а по-друге, законність передбачає, що суди, мають можливість без зовнішнього впливу на судовий процес здійснювати правосуддя та виносити справедливі та законні рішення, тим самим забезпечуючи належний захист прав та свобод громадян, а як результат панування права в українському суспільстві. Саме тому вкрай важливо, щоб держава створила всі необхідні умови для забезпечення безпеки здійснення правосуддя. Одним із таких засобів, на нашу думку, є вироблення сприятливих організаційних та правових умов для забезпечення охорони та підтримання громадського порядку в судах.

\section{Список використаних джерел}

1. Маляренко В. Щодо головних проблем судової влади в Україні. Слово Національної школи суддів України. 2013. № 1. С. 39-49

2. Суд, правоохоронні та правозахисні органи України : Підручник / О. С. Захарова, В. С. Ковальський, В. С. Лукомський та ін.; Відп. ред. В. Маляренко. 3-є вид., переробл. і доп. Київ : Юрінком Інтер, 2007. С. 338-350.

3. Плохой I. I. Поняття громадського порядку. Форум права. 2009. № 3. С. 500505.

4. Настюк В.Я. Щодо розуміння громадського порядку. Проблеми охорони громадського порядку : зб. наук. пр. за матеріалами регіон. круглого столу (19 червня 2014 р., м. Харків). Харків, 2014. С. 59-65.

5. Корнієнко М. В. Роль ОВС України в охороні громадського порядку при ускладненні оперативної обстановки : монографія. Дніпропетровськ, 2001. 370 с.

6. Небеський Ю.С.Адміністративно-правові засади охорони громадського порядку та забезпечення безпеки громадян у сучасних умовах : дис. ... канд. юрид. наук: 12.00.07 / Харківський національний університет внутрішніх справ. Харків, 2008. $227 \mathrm{c}$.

7. Мальський М. М. Публічний порядок у транснаціональному виконавчому процесі. Вісник Національного університету «Львівська політехніка». Юридичні науки. 2015. № 827. С. 79-84.

8. Панова О. О. Поняття, зміст і значення публічної безпеки та порядку. Науковий вісник Херсонського державного університету. Серія : Юридичні науки. 2016. Вип. 6(2). С. 133-136.

9. Зозуля І. В., Довгань О. І. Закон України «Про Національну поліцію»: публічна чи громадська безпека? Форум права. 2015. № 5. С. 85-92.

10. Великий тлумачний словник сучасної української мови (з дод. і допов.) / Уклад. і голов. ред. В. Т. Бусел. Київ; Ірпінь : ВТФ «Перун», 2005, 1728 с. 
11. Про практику розгляду судами клопотань про визнання й виконання рішень іноземних судів та арбітражів і про скасування рішень, постановлених у порядку міжнародного комерційного арбітражу на території України Постанова Пленуму Верховного Суду України № 12 від 24.12.99 р.

12. Про національну безпеку України. Закон України від 21 червня 2018 року № 2469-VIII. Відомості Верховної Ради України, 2018, № 31, ст. 241.

13. Про особливості забезпечення громадського порядку та громадської безпеки у зв'язку з підготовкою та проведенням футбольних матчів. Закон України від 08.07.2011 № 3673-VI. Відомості Верховної Ради Украӥни. 2012. № 9, ст. 64.

14. Про затвердження Положення про патрульну службу МВС Наказ МВС України від 02.07.2015 № 796 URL : http://zakon5.rada.gov.ua/laws/show/z0777-15 (дата звернення: 11.10.2019).

15. Теория государства и права: курс лекций / М. И. Байтин та ін.; под ред. Н. И. Матузова и А. В. Малько. 2-е изд., перераб. и доп. Москва : Юристъ, 2004. 767 с.

16. Крижановський А. Ф. Законність і правопорядок: «сіамські близнюки» чи самостійні правові категорії? Науковий вісник. Львівського державного університету внутрішніх справ. 2011. № 1 (1). С. 27-36.

17. Алексеев С. С. Общая теория права : в 2-х т. Москва : Юрид. лит., 1981. Т.1. $360 \mathrm{c}$

18. Скакун О. Ф. Теорія права і держави: Підручник. 3-те видання. Київ : Алерта; ЦУП, 2011. 524 с.

19. Александров Н. Г. Право и законность в период развёрнутого строительства коммунизма : монография. Москва : Госюриздат, 1961. 296 с.

20. Сагун А. В. Поняття забезпечення законності в діяльності адміністративних судів України. Форум права. 2016. № 2. С. 180-185.

21. Зайчук О. В., Копиленко О. Л., Оніщенко Н. М. та ін. Сучасна правова енциклопедія. За заг. ред. О. В. Зайчука ; Ін-т законодавства Верховної Ради України. Київ : Юрінком Інтер, 2010. 384 с.

\section{References}

1. Malyarenko, V. (2013). Shodo golovnih problem sudovoyi vladi v Ukrayini. Slovo Nacionalnoyi shkoli suddiv Ukrayini, 1, 39-49 [in Ukrainian].

2. Malyarenko, V. (2007). Sud, pravoohoronni ta pravozahisni organi Ukrayini. Kiyiv: Yurinkom Inter [in Ukrainian].

3. Plohoj, I.I. (2009). Ponyattya gromadskogo poryadku. Forum prava, 3, 500-505 [in Ukrainian].

4. Nastyuk, V. (2014). Ya. Shodo rozuminnya gromadskogo poryadku. Problemi ohoroni gromadskogo poryadku : zb. nauk. pr. za materialami region. kruglogo stolu (19 chervnya 2014 r., m. Harkiv). Harkiv [in Ukrainian].

5. Korniyenko, M. V. (2001). Rol OVS Ukrayini v ohoroni gromadskogo poryadku pri uskladnenni operativnoyi obstanovki. Dnipropetrovsk [in Ukrainian].

6. Nebeskij, Yu.S. (2008). Administrativno-pravovi zasadi ohoroni gromadskogo poryadku ta zabezpechennya bezpeki gromadyan u suchasnih umovah (Dis. ... kand. yurid. nauk). Harkivskij nacionalnij universitet vnutrishnih sprav. Harkiv [in Ukrainian].

7. Malskij, M. M. (2015). Publichnij poryadok u transnacionalnomu vikonavchomu procesi. Visnik Nacionalnogo universitetu «Lvivska politehnika». Yuridichni nauki, 827, 79-84 [in Ukrainian].

8. Panova, O. O. (2016). Ponyattya, zmist i znachennya publichnoyi bezpeki ta poryadku. Naukovij visnik Hersonskogo derzhavnogo universitetu. Seriya : Yuridichni nauki, 6(2), 133-136 [in Ukrainian]. 
9. Zozulya, I. V., Dovgan, O. I. (2015). Zakon Ukrayini «Pro Nacionalnu policiyu»: publichna chi gromadska bezpeka? Forum prava, 5, 85-92 [in Ukrainian].

10. Busel V. T. (Red). (2005). Velikij tlumachnij slovnik suchasnoyi ukrayinskoyi movi. Kiyiv; Irpin: VTF «Perun» [in Ukrainian].

11. Matuzov, N. I., Malko, A. V. (Red.). (2004) Teoriya gosudarstva i prava: kurs lekcij. Moskva: Yurist [in Russian].

12. Krizhanovskij, A. F. (2011). Zakonnist i pravoporyadok: «siamski bliznyuki» chi samostijni pravovi kategoriyi? Naukovij visnik. Lvivskogo derzhavnogo universitetu vnutrishnih sprav, 1(1), 27-36 [in Ukrainian]. Russian].

13. Alekseev, S. S. (1981). Obshaya teoriya prava : v 2-h t. T.1. Moskva: Yurid. lit. [in

14. Skakun, O. F. (2011). Teoriya prava i derzhavi. Kiyiv: Alerta; CUP [in Ukrainian].

15. Aleksandrov, N. G. (1961). Pravo i zakonnost v period razvyornutogo stroitelstva kommunizma. Moskva: Gosyurizdat [in Russian].

16. Sagun, A. V. (2016). Ponyattya zabezpechennya zakonnosti v diyalnosti administrativnih sudiv Ukrayini. Forum prava, 2, 180-185 [in Ukrainian].

17. Zajchuk, O. V., Kopilenko, O. L., Onishenko N. M. (2010). Suchasna pravova enciklopediya. Kiyiv: Yurinkom Inter [in Ukrainian].

o. Shurko, Postgraduate Student of the Open International University of Human Development «Ukraine»

e-mail: Shurko25@i.ua; ORCID ID: 0000-0003-1428-035X

\section{Legality as a key principle in ensuring the protection and maintenance of public order in the courts}

The article summarizes the scientific approaches to defining the essence of such concepts as: «assurance of lawfulness» and «lawfulness», on the basis of which we propose our own definition of the content of these categories. It is emphasized that in legal literature the concept of justice is identified with the category of justice. Emphasis is placed on scientific approaches to understanding the terms public order and public order. Their relationship is analyzed.

It has been found that, despite the substantial substantive similarity of «public order» and "public order», however, not identical concepts. It is substantiated that it is advisable to speak about public order in the context of international relations, principles of organization and activity of public authorities, their relations with each other. Instead, when it comes to order as a state of regulation of public relations, behavior in public cities, protection and protection of this order, it is not a matter of public order, but of public order.

It has been established that in the most general sense, legitimacy must be interpreted as the starting point, the idea underlying any activity, regardless of the sphere of social relations. First of all, it envisages the constant observance of all the subjects of the law of the current legislation, and thus helps to ensure the rule of law in society.

Generally, legality, as a key basis for ensuring the protection and maintenance of public order in the courts, has two key aspects: first, it aims to ensure that the 
activities of the courts are lawful and in accordance with the rules of current law, and also international standards that are generally recognized in this field; and second, legality implies that courts have the power to exercise justice and make fair and lawful decisions without external influence on the judicial process, thereby ensuring the proper protection of citizens' rights and freedoms, and as a result of the rule of law in Ukrainian society.

Keywords: legality; justice; law and order; public order. 